\title{
SEISMIC CHARACTERISTICS AND SEDIMENTARY DISTRIBUTION ON THE SOUTH SHETLAND ISLANDS CONTINENTAL MARGIN, ANTARCTICA
}

\author{
Fabio José Guedes Magrani and Arthur Ayres Neto
}

\begin{abstract}
This work consists in characterizing the sedimentary distribution of the South Shetland Islands continental margin, Bransfield Strait, Antarctica, through the interpretation and correlation of high-resolution seismic profiles and geological samples. The analysis of echo-characters, seismic amplitudes and their correlation with the collected samples, revealed five different echo types. Echo types I and II have good seismic resolution and are characterized by continuous sharp bottom echoes with subparallel reflections. Echoes III and IV are characterized by diffuse and very prolonged bottom echoes with no subbottom reflectors. Echo V is associated with glacial deposits on the upper slope in response to deglaciation and transport of coarse grains in a muddy matrix and is characterized by diffraction hyperbolae. The echo-characters showed good correlation with geological samples collected along the Bransfield Strait and bays of the King George Island, but the correlation with the seismic amplitude map was not as obvious. Echo I shows medium-high amplitudes and samples within its area of occurrence (AM-02 and AM-14) indicate silty sand and sandy silt, respectively. Echo II presents the lowest seismic amplitudes and the sample collected within its area (AM-17) shows approximately $90 \%$ mud content. Echoes III and IV, located on the shallowest portions of South Shetland's continental margin, demonstrate medium-low amplitude values, and are related to samples AM-01 and AM-04, both classified as sandy silt with approximately $35 \%$ sand.
\end{abstract}

Keywords: Bransfield Strait, echo-characters, high-resolution seismic, sedimentary analysis.

RESUMO. 0 presente trabalho consiste na interpretação integrada da sísmica de alta resolução e da amostragem geológica, a fim de caracterizar a geologia de fundo na região da margem continental das Ilhas Shetland do Sul, Estreito de Bransfield, Antártica. A caracterização geológica foi realizada através da análise de ecocaráteres, mapas de amplitude sísmica e sua correlação com os sedimentos coletados. Cinco diferentes ecocaráteres foram identificados e classificados. Ecos I e II demonstram boa resolução e são caracterizados por ecos contínuos e nítidos com reflexões subparalelas. Ecos III e IV são caracterizados por ecos difusos, muito prolongados e com ausência de refletores subparalelos. 0 Eco $\mathrm{V}$ está associado a depósitos glaciais no talude superior, em respostas ao degelo, e ao transporte de grãos grossos em uma matriz mais fina. Além disso, é caracterizado pela presença de hipérboles de difração. Os ecocaráteres mostraram boa correlação com os testemunhos geológicos coletados no Estreito de Bransfield e nas baías da Ilha Rei George, mas não apresentaram uma relação óbvia com o mapa de amplitudes. 0 Eco I possui amplitudes médio-altas e as amostras contidas em sua área (AM-02 e AM-14) indicam, respectivamente, um conteúdo de areia siltosa e silte arenoso. 0 Eco II apresenta os menores valores de amplitude com conteúdo de lama (argila + silte) de aproximadamente 90\%, conforme a amostra AM-17. Os Ecos III e IV, localizados nas porções mais rasas da margem continental das Shetland do Sul, demonstram valores médio-baixos de amplitude e se relacionam às amostras AM-01 e AM-04, ambas siltes-arenosos com conteúdo de areia de aproximadamente $35 \%$.

Palavras-chave: Estreito de Bransfield, ecocaráteres, sísmica de alta resolução, análise sedimentar. 


\section{INTRODUCTION}

The high-resolution seismic is a practical geophysical method based on the emission of acoustic waves, considered an important tool for the indirect investigation of the sea bottom and subbottom nature.

The shallow areas of the Antarctic Peninsula region, especially fjords, bays and embayments, are the appropriate places to investigate the variation of marine deglaciation environments; because the glacier advances and retreats in such environments are decisive factors in the depositional processes and sedimentary distribution (Khim \& Yoon, 2003).

Currently, sedimentary records of the evolution of the ice covers and the glacier migration in the area of the South Shetland Islands (SSI) are preserved in marine sediments within the bays and fjords. However, there is still a shortage of geological and high-resolution geophysical data that completely clarify the glacial history and make possible the understanding of the influence of the ice covers for the global climate.

The absence of sediments older than 14.8-14.1 ka, in the bays of the King George Island, indicate that the oldest sediments were eroded and deposited in the fjords outlets, close to the abrupt slope of the Bransfield Strait, in huge underwater fans during the Last Glacial Maximum (LGM) (Simms et al., 2011).

The purpose of this work is to correlate maps of seismic amplitude, maps of echo-character distribution and sediment cores, in order to generate maps that allow the correlation of the highresolution seismic reflection $(3.5 \mathrm{kHz})$ echo types with the sedimentary distribution in the continental margin of the South Shetland Islands.

\section{Echo-characters}

The acoustic impedance is, by definition, the product between the compressional acoustic velocity (Iongitudinal or primary) and the medium density $\left(\mu_{o}\right)$ (Mosher \& Simpkin, 1999). The elastic waves (or seismic waves) travel with different velocities in different lithologies.

High frequency and short wavelength sources restricts the penetration capacity in the subsurface, although they present a high-resolution, suitable for particular studies of the bottom and subbottom comprising tens of meters to one hundred meters.

The amplitude of the reflected signal is a function of the impedance contrast between the sea water and the bottom sediment. However, for normal angles of incidence to the reflector's surface, a simplification of the relationship may be defined. In this case, the reflection coefficient $\left(R_{c}\right)$ is defined as the ratio between the amplitude of the reflected signal $\left(A_{R}\right)$ and the amplitude of the incident wave $\left(A_{i}\right)$, through Sharma's (1997) equation (Eq. 1), where $\rho$ is the density and $V$ is the velocity of the primary wave.

$$
R_{c}=\frac{A_{R}}{A_{i}}=\frac{\left(\rho_{2} V_{2}-\rho_{1} V_{1}\right)}{\left(\rho_{2} V_{2}+\rho_{1} V_{1}\right)}
$$

Equation 1 - Equation for the Reflection Coefficient $\left(R_{c}\right)$ (Sharma, 1997). $R_{c}$ is the ratio between the amplitude of the reflected wave and that of the incident wave, for normal incidences.

The echo-characters are a set of characteristics of the reflected echo, arising out of the interaction of the signal with the bottom. The echo return is produced by the contrast of acoustic impedance of the media, and it is related to the type of the bottom material (grain size, compaction, etc.), the sedimentary layers in the subsurface (reflection coefficient, layer thickness, multiple internal reflections, etc.) and the bottom morphology (diffraction, layer extension, lateral variation in the spacing of the layers, etc.) (Veronez Júnior et al., 2009).

The echo-characters occurrence and distribution are closely related to the distribution of the sedimentary characteristics (Ayres Neto, 2000; Veronez Júnior et al., 2009) and reflect the active sedimentary processes in the area (Damuth, 1975). Exploration has been carried out in different geologic environments since the establishment of the bases of the technique by Damuth (1975) and Damuth \& Hayes (1977) by characterizing the sea bottom geology using the echo-characters. Hong \& Chen (2000) used echocharacters to identify sedimentary processes in the continental margin of Taiwan. George et al. (2002) used seismic patterns to identify areas with submarine landslides and erosive processes in the Gulf of Mexico continental slope. Duck \& Hebert (2006) used the technique for locating gas-saturated sediments in lakes of Scotland, and Yoon et al. (2004) used the echo-characters for mapping the northern continental margin of the South Shetland Islands, in order to elucidate the glaciomarine sedimentary processes that took place along the Quaternary.

\section{Seismic Amplitude}

The seismic amplitudes, originated by the return signals of the acoustic waves, are a function of the acoustic impedance, product of the velocity and density, and dependent on the elastic properties of rocks. The greater the impedance contrast, the greater will be the Reflection Coefficient $\left(R_{c}\right)$ (Eq. 1) and, therefore, the larger the amount of reflected energy.

As, in a general way, both density and the velocities usually increase with the depth $\left(\rho_{2}, V_{2}>\rho_{1}, V_{1}\right)$ (Eq. 1), most of the strong reflections will be positive and without a phase change (Sharma, 1997). In that way, sediments that present a higher 


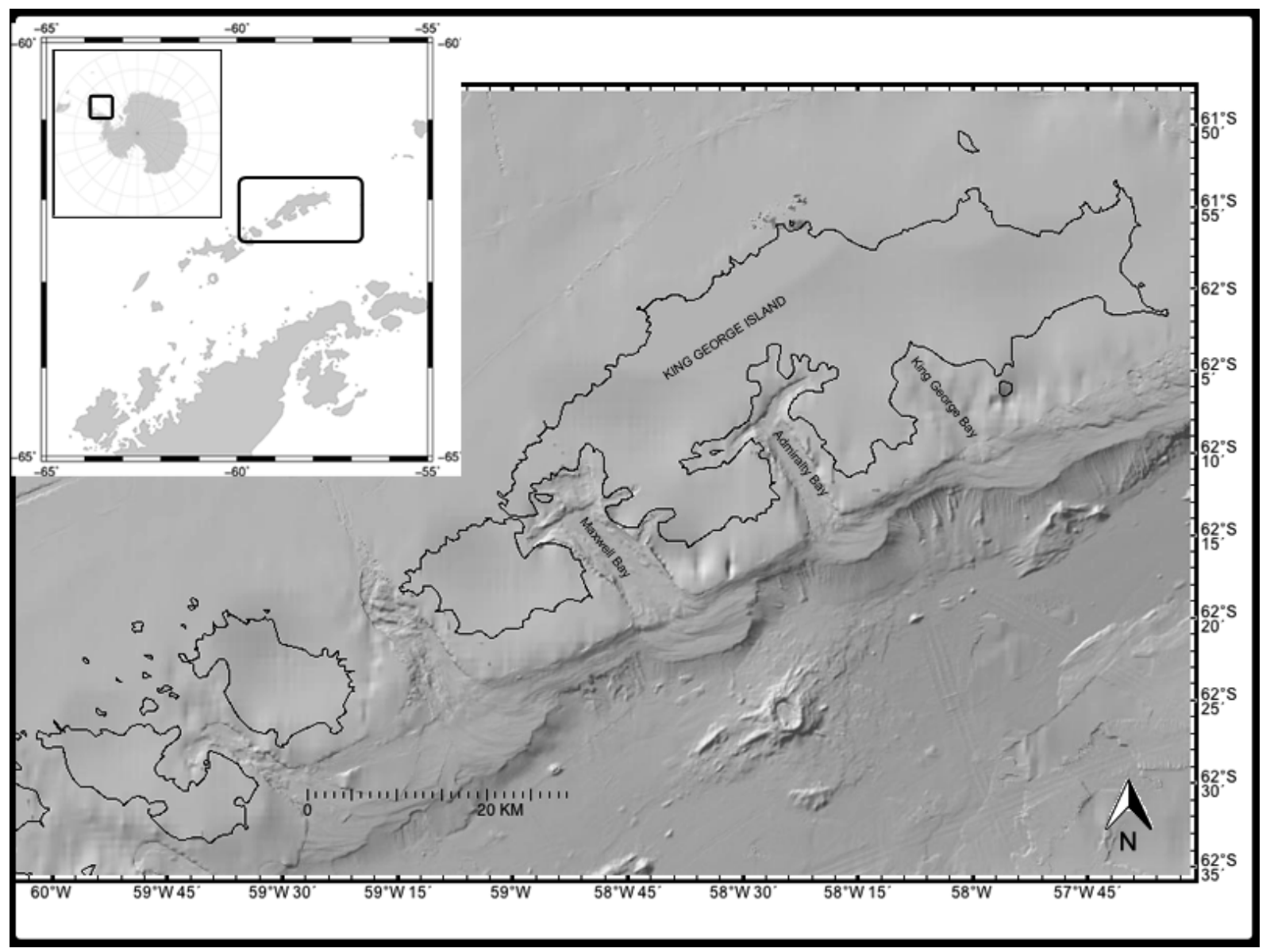

Figure 1 - Location of the area under investigation, at the South Shetland Islands, Antarctica. Bathymetric GMRT 2.3 and GEBCO_08 maps. Shoreline data compiled by SCAR Antarctic Digital Database.

density and/or velocity (in function of the compaction degree, larger grain size, etc.) will be more reflexive.

The geologic interpretation of the seismic amplitudes has the main purpose of correlating the seismic record amplitudes with different lithologies or bottom sediments present in the surroundings.

During this work, the amplitudes obtained in the seismic record were analyzed and interpreted in the light of the echocharacters and their relationship with the bottom geology, in order to obtain the superficial sedimentary distribution of the South Shetland Islands continental margin.

\section{Studied area}

The area under investigation is located in the Bransfield Strait, along the Pacific margin of the Antarctic Peninsula, between the South Shetland Islands (with average width of approximately $100 \mathrm{~km}$, extending over $470 \mathrm{~km}$ from Clarence Island to Low Island) and the Antarctic Peninsula (Fig. 1). This region is situated in a glacial environment dominated by glaciomarine processes (under the influence of both processes).

The seismic acquisition was mainly concentrated in the south of King George Island, between latitudes $-62.0390^{\circ}$ and $62.3978^{\circ}$, and longitudes $-57.3824^{\circ}$ and $-58.9347^{\circ}$, in depths between 100-1300 m (Fig. 2).

Situated on King George Island, Maxwell and Admiralty bays are fjords with elongated U-shaped valleys with extensions of approximately 14 to $16 \mathrm{~km}$, with steep walls from the center of the bay towards the coast, and presence of alpine glaciers (or valley glaciers). Extensive submarine fans that curve northwards are present in the outlets of the fjords, which are the result of the redistribution of the deposits in the upper slope during the Last Glacial Maximum (LGM) when the glaciers reached the Bransfield Strait. Sediments older than this event were eroded from the bays by the glaciers and deposited in those fjord's outlets. Presently, the ice cover retreated about $20 \mathrm{~km}$ from its position during the LGM, 14.8-14.1 ka (Simms et al., 2011). 


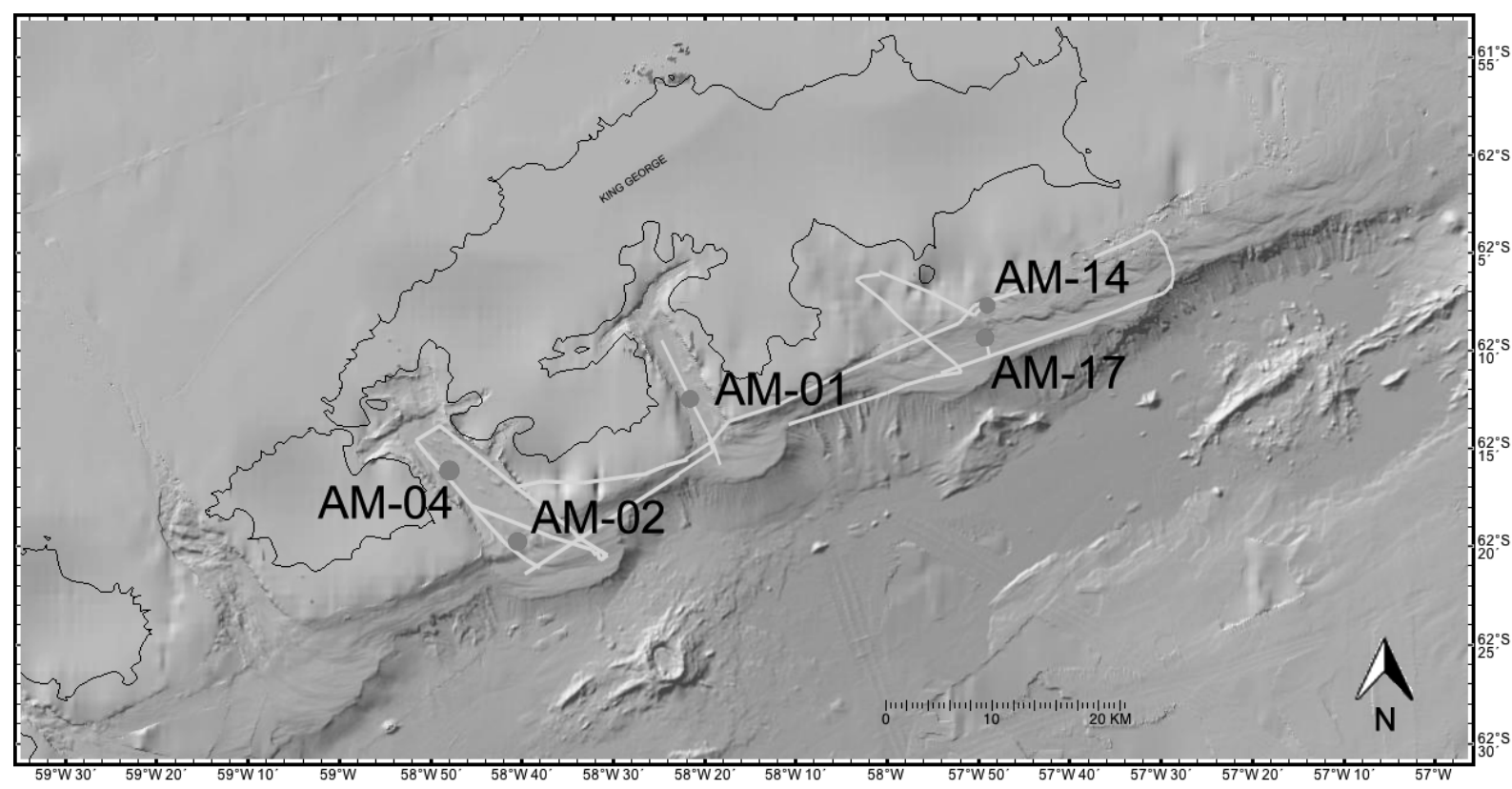

Figure 2 - Positioning of the seismic lines and geologic cores collected during the OPERANTARXXVIII, Antarctica - 2009. The yellow lines represent the navigated lines during seismic acquisition, and the red dots the sampling sites.

Water depths range from up to $550 \mathrm{~m}$ at the center of Admiralty Bay, and $500 \mathrm{~m}$ at the center of the Maxwell Bay. Farther on, they dive abruptly into a steep slope towards the Bransfield Strait.

The Bransfield Strait is a recent retro-arch rift, forming the Strait and its basin (Barker, 1982; Barker \& Austin, 1988).

The Bransfield Basin formation was a response to the consumption of the oceanic crust in the subduction zone of the South Shetland Islands (SSI), which is still active (Gamboa et al., 1988). Subduction of the Pacific Plate under the Antarctic Plate originated an extensive magmatic arc, whose remnants form what today constitutes the Antarctic Peninsula (Francis et al., 2006). The SSI, located to the northeast of the Antarctic Peninsula, is a magmatic arc associated with this subduction area, and it is separated from the Antarctic continent by the Bransfield rift.

The South Shetland Islands are made up of magmatic Jurassic-Quaternary formations, overlying the sialic basement made up of schists and sedimentary rocks. Inside the Admiralty Bay and other bays influenced by glaciers, the sea bottom is dominated by glacial deposits, such as eskers, moraines, flutes, kame terraces and clast pavements (Rosa et al., 2010).

\section{Glaciomarine Environments}

In glacial environments, ice and meltwater are the main agents of erosion, transport and sediments deposition. These compre- hend the environments in direct contact (glaciogenic), adjacent or influenced by glaciers (proglacial).

Assine \& Vessley (2008) subdivide the glaciomarine environments into three main classes of process domains in relation to the glacier position:

1) subglacial (the processes and deposits directly associated with the glacier dynamics);

2) proximal proglacial (the processes suffer a strong influence from the glacier margins);

3) distal proglacial (dominated by the marine processes).

The rain-out is one of the most important processes in the glaciomarine environment, when sediments present in the meltwater are expelled from the glacier and part of this sedimentary load (finer parts), form plumes that stays in suspension in the water until deposition. Subaqueous currents of meltwater involve high-energy continuous flows, depositing the coarser fraction under the form of lobes. Due to the high sedimentation rate and coarse particles, the fans may present steep depositional slopes, even where deposition is entirely subaqueous (Assine $\&$ Vessley, 2008).

The basic components of the glacial environments are the glaciers, which are important elements of erosion and relief formation, and they are closely associated to meltwaters and debris. 
Glaciers are formed from the snow accumulation, originated from compaction of the accumulated flakes due to the weight of the overlaying layers and their recrystallization, and they move by gravity. However, in order to be formed they depend on factors such as low temperatures, high precipitation and low evaporation rates (Reineck \& Singh, 1975).

In spite of their downward gradient constant movement, their fronts can move forward or retreat, due to variation of their accumulation rates and ablation. Accumulation rates smaller than the ablation, cause the retreat and glacier shrinkage.

Below a glacier, the primary pattern of erosion is controlled by the basal thermal regime. In other words, the temperature variations control the ice deformation rates and the amount of meltwater, which will lubricate the substratum. The sedimentary deposition varies in accordance with the distance in relation to the margin of the glacier. This way, sediments may be deposited by the glaciers or transported by icebergs, or still be remobilized by currents according to the active processes inside the waterbody (Assine \& Vesely, 2008).

Sedimentation in glacial environments may take place directly from the glacier or ahead of them, where the transportation and deposition agents are currents of meltwater and gravity flows.

Due to the great competence of the glaciers to remobilize sediments, in the studied area there were expected accumulations of gravel, sand and mud near the ice fronts, due to the glacier movements and currents of subglacial meltwater (Conceição, 2009).

In the subglacial zone, glaciers play a main role in the sedimentary deposition, building, for instance, morainal features. Moraines are important features of the glacial environments, and they basically form deposits of clastic sediments (till), commonly coarse, with poor grain size selection, massive aspect and abundance of faceted and/or grooved clasts. Till's most common aspect shows clasts with different forms and sizes (from granules to boulders) in a fine-grained matrix.

Moraine deposits are formed by the direct action of glaciers in linear or arched crests of glacial debris that laterally follow the glacier, beside their frontal margin, indicating the movement of their fronts (Reineck \& Singh, 1975). They may be classified as terminal, lateral and median (the meeting zone of two glaciers).

In the studied area, features were found associated with submarine morainal banks, in the inner portion of the fjords, along belts perpendicular to the longest axis of the bays, which will be evaluated in subsequent works concerning the regional glacier dynamics and evolution.
In areas that are away from the direct influence of the glaciers, a fine-grained sedimentation predominates, as a response to the locally dominant marine processes.

\section{METHODOLOGY}

The seismic data and samples were collected during the OPERANTAR XXVIII operation (November, 2009), on board of NApOc Ary Rongel (H-44), supported by the Brazilian Navy and the Brazilian Antarctic Program (PROANTAR). The high-resolution seismic equipment, Subbottom Profiler Edgetech 3200, was regulated with variable gains and TGV, pulse between $50 \mathrm{~ms}$ and $100 \mathrm{~ms}$, fixed power to $100 \%$, and frequencies in two windows: $0.5-2.7 \mathrm{kHz}$ and $0.5-4.5 \mathrm{kHz}$.

A total of $350 \mathrm{~km}$ of seismic lines was acquired (Fig. 2) covering an area of approximately $2500 \mathrm{~km}^{2}$. During interpretation, amplitude maps were generated using the SMT KINGDOM software, picking the first positive peak of the sea bottom reflector.

Sediment samples were collected by a gravity corer (with approximately $400 \mathrm{~kg}$ and $6 \mathrm{~m}$ long) in seven different stations. Five cores were used in this work (Fig. 2). Samples were collected along the Bransfield Strait and within the Admiralty, Maxwell and King George bays. Core locations were planned to sample on the different echo-characters observed in the seismic records.

Cores were sectioned at every meter and analyzed by the Multi-Sensor Core Logger (MSCL) at the Sedimentology Laboratory of the Geosciences Institute of the Universidade Federal Fluminense, where values for the acoustic impedance, $P$-wave (primary, compressional) velocities, and density were obtained, along the cores. Subsequently, the cores were cut, analyzed and described, based on their grain size, color and texture for classification.

\section{RESULTS}

\section{Echo-characters}

Five different echo-character types were identified, grouped in different categories (Fig. 3) in order to create an echo-character distribution map. The echoes are strongly associated with the morphology, microtopography, subsurface geometry and texture of the oceanic bottom.

Echo $I$ is characterized by a continuous and sharp bottom, with weak subparallel reflections. This echo is distributed along all the continental margin of the South Shetland Islands, except in areas shallower than $200 \mathrm{~m}$. (Figs. 3 and 4). According to Yoon et al. (2004), this echo represents semiconsolidated sediments, reworked by bottom currents and it is defined as IA in their work in the northern portion of the South Shetland Islands shelf. 


\begin{tabular}{|c|c|c|}
\hline ECHO & DESCRIPTION & \\
\hline I & $\begin{array}{l}\text { Continuous sharp bottom echo } \\
\text { with weak subparallel } \\
\text { reflexions }\end{array}$ & \\
\hline II & $\begin{array}{l}\text { Continuous sharp bottom echo } \\
\text { with strong subparallel } \\
\text { reflexions }\end{array}$ & \\
\hline III & $\begin{array}{l}\text { Very prolonged bottom echo } \\
\text { with multiples and no subbottom } \\
\text { reflectors }\end{array}$ & \\
\hline IV & $\begin{array}{l}\text { Very prolonged bottom echo } \\
\text { and no subbottom } \\
\text { reflectors }\end{array}$ & \\
\hline $\mathbf{V}$ & $\begin{array}{l}\text { Large irregular overlapping } \\
\text { hyperbolae with widely varying } \\
\text { vertex elevations }\end{array}$ & \\
\hline
\end{tabular}

Figure 3 - Seismic profiles showing the five echo-character types found along the South Shetland Islands continental margin.

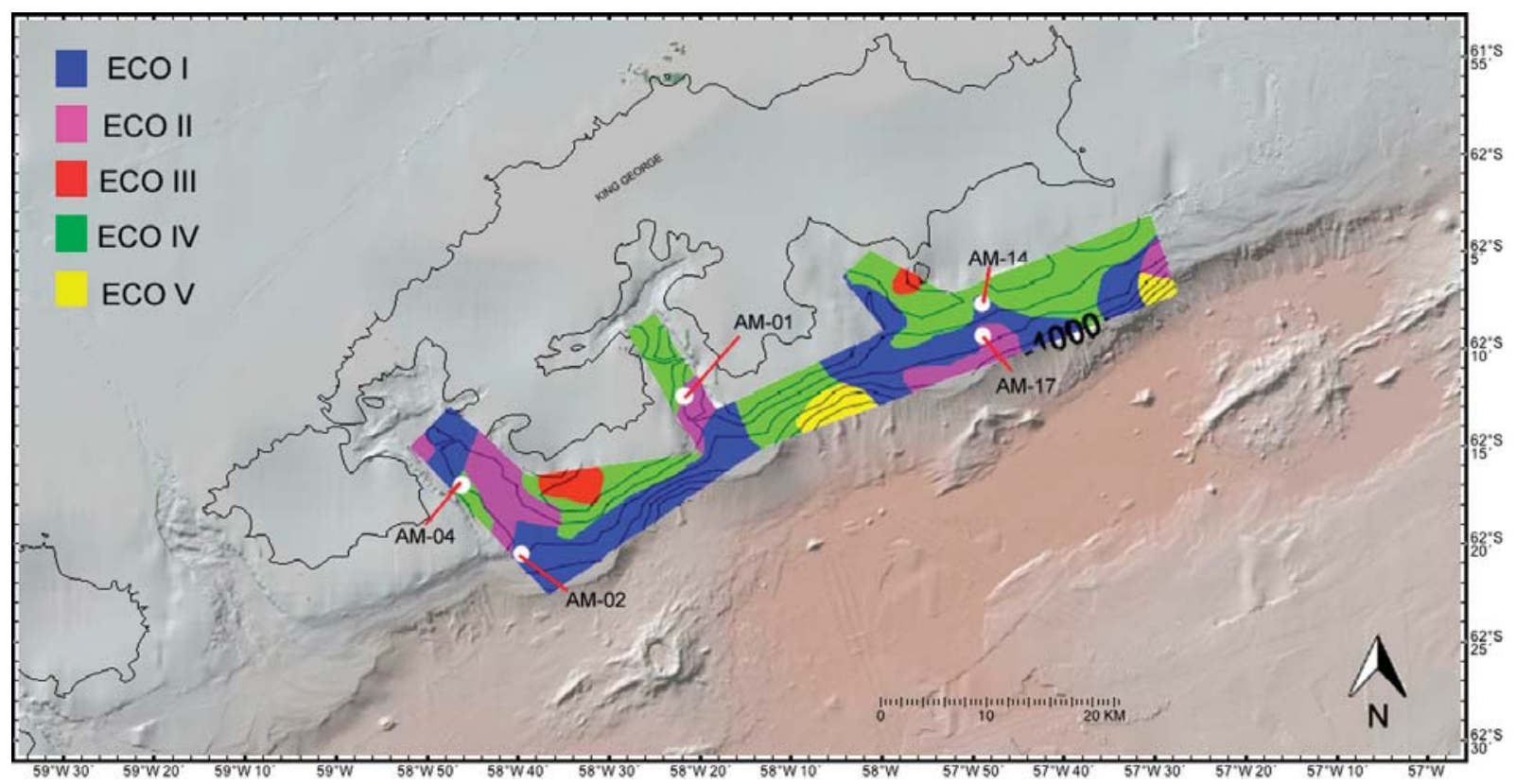

Figure 4 - Map of the echo-characters present at the South Shetland Islands continental margin.

Echo II is characterized by a continuous and sharp bottom, with strong and numerous subparallel reflections. It is found between the 400 and $800 \mathrm{~m}$ isobaths (Figs. 3 and 4). This echo corresponds to the IB echo type described by Damuth (1975) and Damuth \& Hayes (1977), and to the IIA echo type defined by Yoon et al. (2004) as hemipelagic deposits.
Echo III is characterized by an elongated, diffuse bottom, with several multiples and absence of subbottom reflectors. This type occurs in shallower areas, in water depths of less than $200 \mathrm{~m}$ (Figs. 3 and 4). According to Damuth (1975) classification, this echo is classified as IIA-1 and according to Damuth \& Hayes (1977), as IIB. 


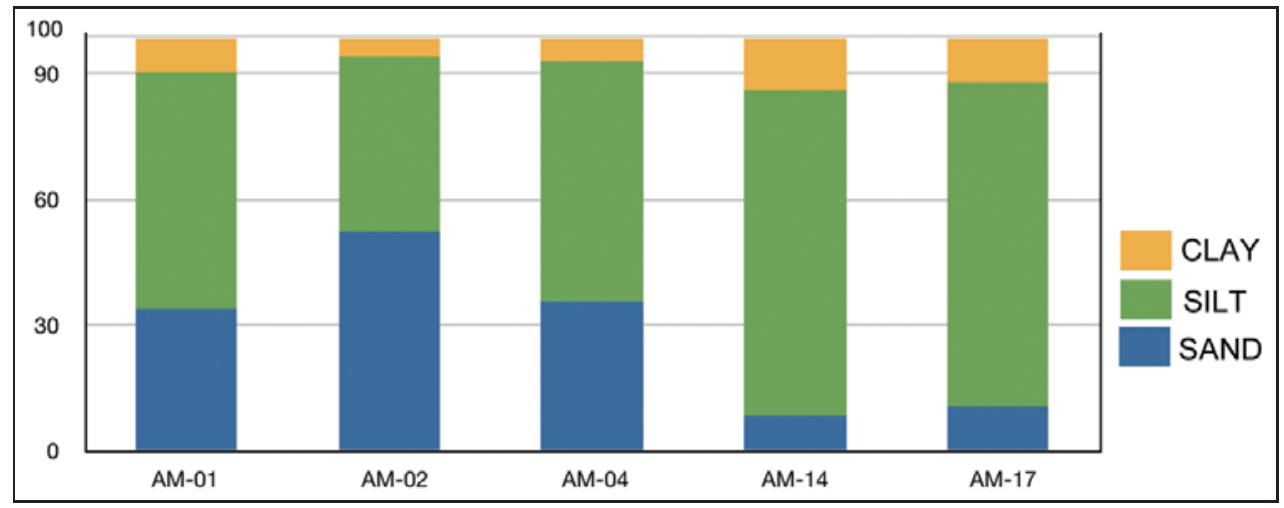

Figure $\mathbf{5}$ - Average grain size along the sediment cores with the average percentages of clay, silt and sand.

Echo IV is characterized by an elongated, diffuse bottom, and subbottom reflectors are absent, as in Echo III. Multiples are also not present (Figs. 3 and 4) because it occurs in depths varying between 200 and $600 \mathrm{~m}$. Both echoes III and IV, corresponds to echo IIB of Yoon et al. (2004) and represent till deposits on the continental shelf and upper slope.

Echo $\mathrm{V}$ is characterized by a series of overlaid diffraction hyperbolae, with a wide range of peak positions above the sea bottom, and low seismic resolution (Figs. 3 and 4). It is found between the 600 and $1400 \mathrm{~m}$ isobaths. It is classified by Damuth (1975) as IIB-1, while in the works of Damuth \& Hayes (1977) and Laine et al. (1986) the echo is classified as IIIA. In general, it is related to mass sliding or pelagic sedimentation on steep slopes (Damuth \& Hayes, 1977 and Laine et al., 1986).

\section{Sedimentary Analysis and Physical Characterization}

Grain size analysis allowed the identification of two main categories of sediments. Samples AM-01, AM-02 and AM-04, collected on the mouths of Maxwell and Admiralty bays, have above $30 \%$ of sand, between $40 \%$ to $57 \%$ of silt and less than $10 \%$ of clay. Samples AM-14 and AM-17, collected outside the fjord outlets, to the NE of the studied area, present $10 \%$ of sand, $80 \%$ silt and 7 to $14 \%$ of clay. These samples suggest less influence of sediments drifted by glaciers and a stronger marine influence.

All samples presented a homogeneous dark-gray color along the cores, and absence of carbonate shells.

The average percentages of sand, silt and clay contained in the samples (mean for the whole core) are presented in Figure 5.

Data obtained by the MALVERN 2000 laser granulometer, identified core AM-01 as bimodal, characterized by sandy silt, with poorly-sorted sediments varying between coarse silt and fine sand.
Core AM-02 is classified as unimodal silty sand, varying between very coarse silt and fine sand, with very poorly-sorted sediments with silt sand intercalations.

Cores AM-01 and AM-02 show significant grain size variations along the cores. Core AM-01 has four different sand layers (above $50 \%$, reaching $70 \%$ of sand) interlayered with mud (between $70 \%$ to $80 \%$ of mud).

Core AM-04 is very similar to core AM-01, sandy silt, basically unimodal, varying between very coarse silt and fine sand.

Core AM-14 is unimodal, with very poorly-sorted sediments, classified as coarse silt, with gravel (dropstones).

Core AM-17 is unimodal, poorly-sorted coarse silt.

Measurements of the P-waves velocity $\left(V_{p}\right)$ and gamma density, using the Multi-Sensor Core Logger (MSCL), allowed the determination of the acoustic impedance values for each one of the collected cores. Table 1 shows values of acoustic impedance. It is noticed that cores AM-01, AM-02 and AM-04, with higher sand contents, presented values above 2550 N.s.m ${ }^{-3}$, while samples AM-14 and AM-17, with higher mud content, present values below 2550 N.s.m ${ }^{-3}$.

Table 1 - Acoustic impedance for each one of the collected cores.

\begin{tabular}{|c|c|}
\hline Sample & Mean Impedance (N.s.m ${ }^{-3}$ ) \\
\hline AM-01 & 2994.95 \\
AM-02 & 3107.92 \\
AM-04 & 2603.13 \\
AM-14 & 2580.32 \\
AM-17 & 2677.44 \\
\hline
\end{tabular}

The longest core, AM-04, recovered $3.22 \mathrm{~m}$ of sediments, and the smallest core, AM-02, only $0.84 \mathrm{~m}$. They were collected at depths of $285 \mathrm{~m}$ and $576 \mathrm{~m}$, respectively, and this was the 


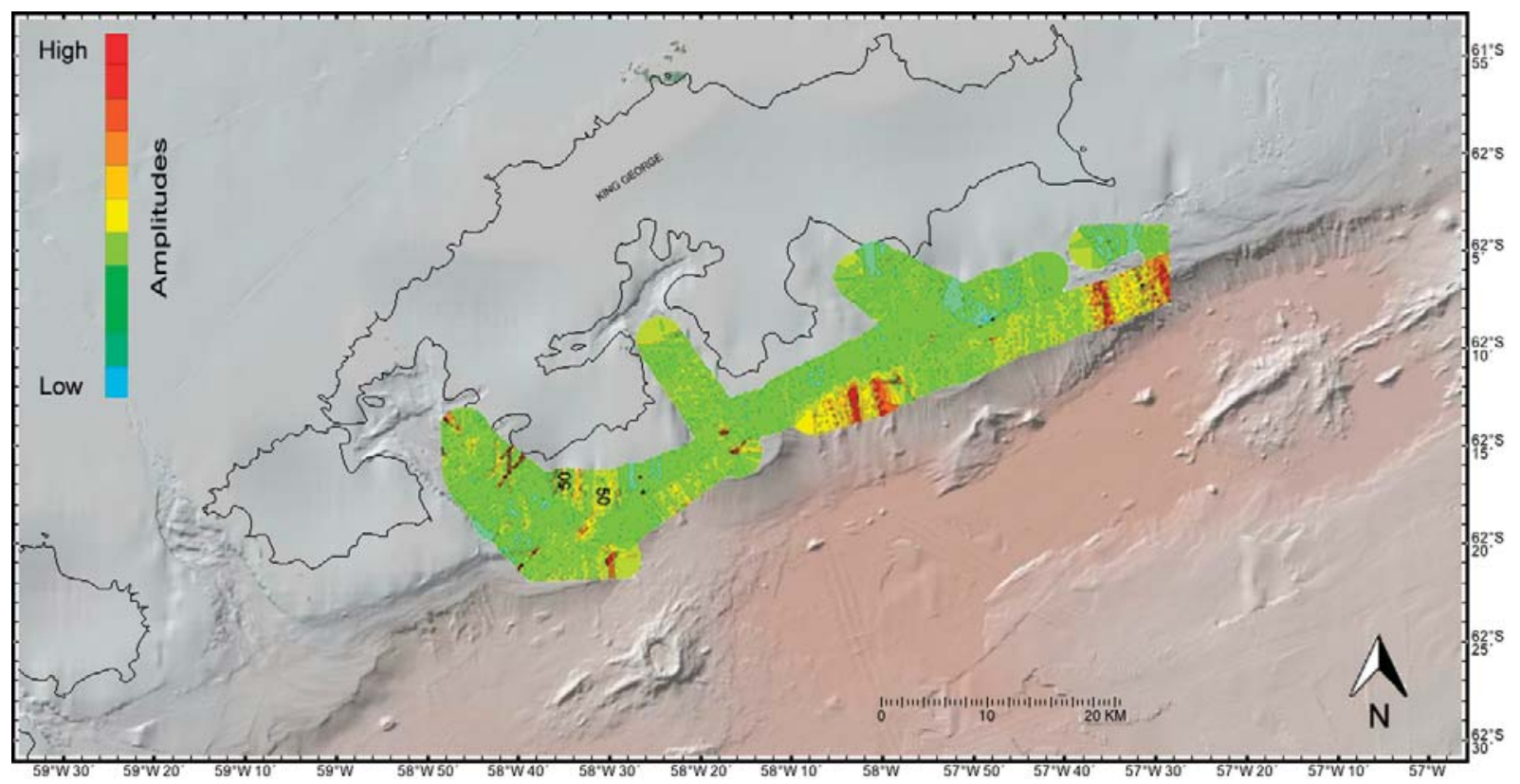

Figure $\mathbf{6}$ - Map of seismic amplitudes, from the first positive peak regarding the sea bottom.

deepest sampling point. Core AM-02 demonstrated the smallest sediment recovery and highest average content of sands among the cores $(52.3 \%)$.

The seismic amplitude distribution map was created in order to verify the direct relationship between the amplitudes and the bottom geology (Fig. 6). In general, the entire area presents medium to low amplitudes, except in two areas located in the central portion and to NE. In these two areas, both in deeper waters, 800-1200 m, the observed amplitudes are clearly higher than the average for the area, and they are probably related to the coarse glacial deposits when glaciers reached the shelf break and following slumps on the upper slope.

The geologic characterization of the sea bottom was carried out analyzing the echo-characters, seismic amplitude maps and their correlation with the superficial sediments.

Some examples of seismic profiles along the continental margin of the SSI are represented in Figure 7.

Inside and at the mouth of Maxwell and Admiralty fjords, occur thick sedimentary packages of glaciomarine muds with ten to one hundred meters. However, at the Maxwell Bay, sedimentation was more extensive and the sedimentary thickness is a few tens of meters thicker than at the Admiralty Bay.

The Bransfield Strait presents thin sedimentary cover or absent subbottom sediment layers above acoustic basement. The occurrence of diffraction hyperbolae in some portions of the upper continental slope suggests glacial deposits and slumps.

\section{DISCUSSION}

The maximum core penetration reached $5 \mathrm{~m}$, but the maximum recovery was $3.22 \mathrm{~m}$. Such a core loss is attributed to sediment compaction and some content loss during the corer ascent.

Echo I showed medium-high impedance values and cores within its area (AM-02 and AM-14) indicate, respectively, silty sand and sandy silt composition. Core AM-02 presented the highest impedance value (above 3100 N.s.m ${ }^{-3}$ ) and reflects the highest sand content among the cores (52.3\%). Core AM-02 is from the mouth of Maxwell Bay, collected at a depth of approximately $570 \mathrm{~m}$, in the upper slope portion, where coarser material transported by glaciers and icebergs in colder times were expected. Core AM-14, by its turn, presented an average impedance value of 2536 N.S.m ${ }^{-3}$ and the lowest percentage of sand (around 8\%).

Core AM-14 presented the lowest sand percentage, and average values for impedance. However, it was collected within the area of Echo I occurrence, whose seismic characteristic indicates sandier sediments. An explanation for this discrepancy may be related to the quality of the sample positioning, due to the absence of a submarine acoustic positioning system, generating positioning uncertainties on the order of dozens of meters. Considering that core AM-14 is very close to the limit between echoes I and IV (Fig. 4), it is possible that, due to the corer feathering as a function of marine currents and the positioning uncertainties, it may have effectively sampled within the area of the Echo IV occurrence. 

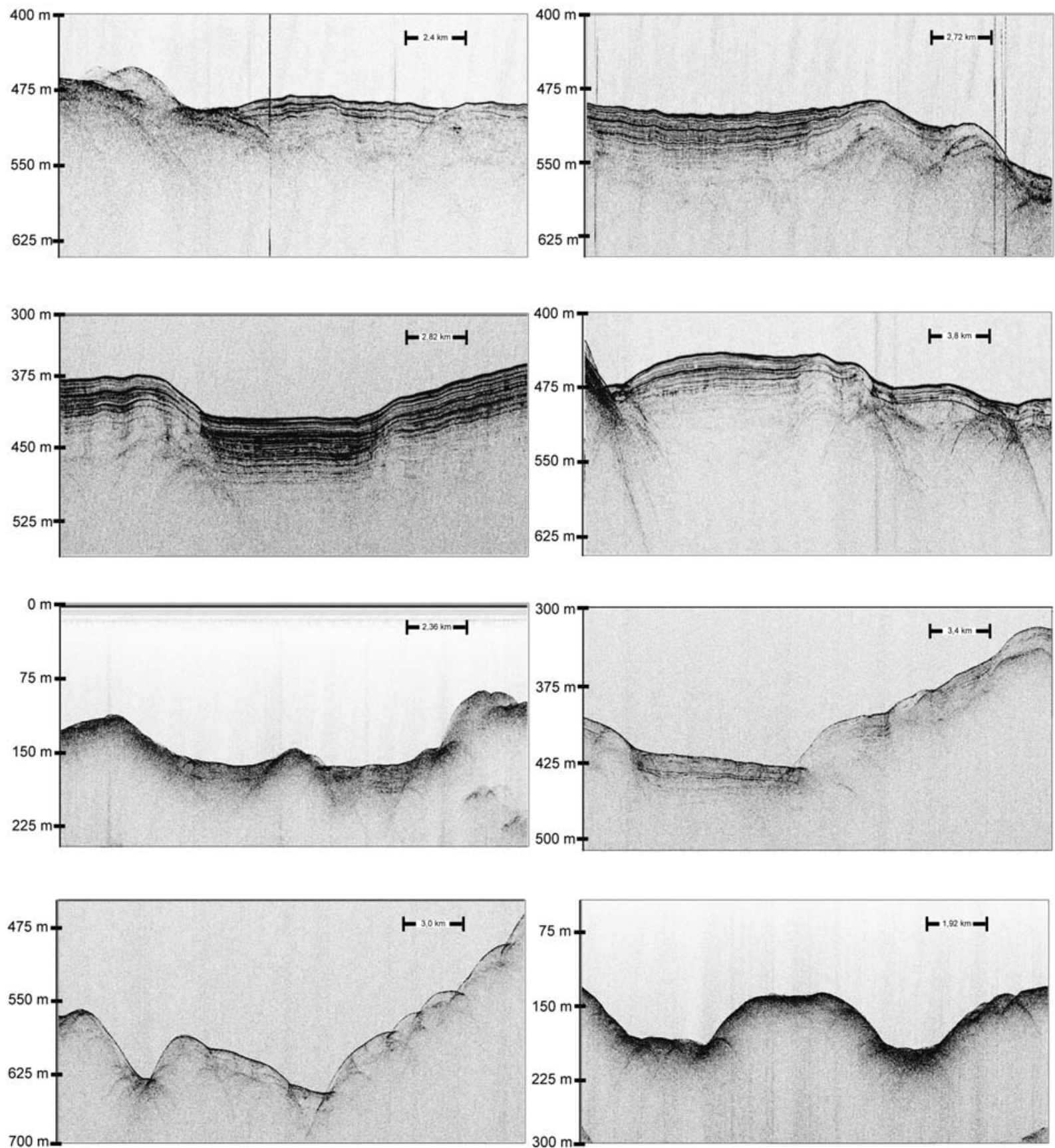

Figure 7 - Examples of seismic profiles found in the studied area. The profiles are arranged in lines by collection site. In the first line, there is a pair of typical seismic records, found within the Admiralty Bay; the second line shows records that are traverse and parallel to the Maxwell Bay, respectively, both acquired near the fjord's mouth. Third and fourth lines show profiles found at the King George Bay and Bransfield Strait, respectively. Depths were calculated with the sound velocities in the water at $1500 \mathrm{~m} / \mathrm{s}$.

Echo II presents the lowest impedance values (2395 N.s. $\mathrm{m}^{-3}$ ), due to its high clay and silt content, as evidenced by core AM-17 (located within Echo Il's area), with approximately $88 \%$ of mud. This echo-character occurs in an area with average depth between 400-800 m.
Echo IV presents medium-high impedance values, which are connected with cores AM-01 and AM-04, both classified as sandy silt. These cores present sand contents around 35\% and impedance values of 2859 N.s.m ${ }^{-3}$ and 2593 N.s.m ${ }^{-3}$, respectively. In this case, the different acoustic impedance values may 


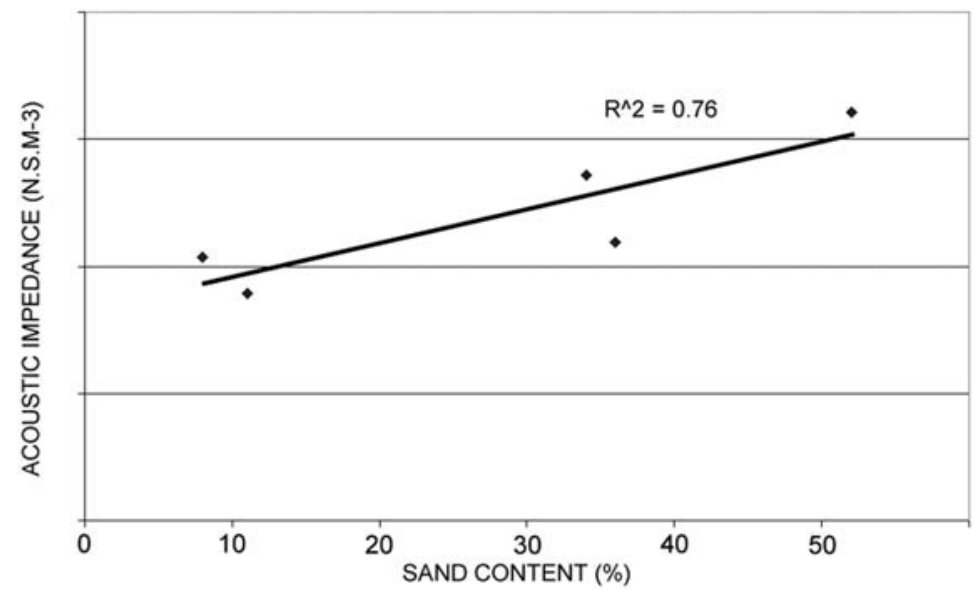

Figure 8 - Correlation chart between the sand content and the acoustic impedance of the collected samples.

be explained by the presence of some layers with coarser grains along core AM-01 (between $50 \%$ and $70 \%$ of sand), what would exert some influence on density values, while core AM-04 shows little grain size variations, and a maximum of $45 \%$ of sand.

Echoes III and IV are quite similar, indicating sediments that are probably till deposits on the continental shelf and upper slope, as also found by Yoon (Yoon et al., 2004) in the northern portion of the SSI continental margin. However, most parts of Echo III are located in the shallowest portions of South Shetland Islands continental shelf. Echo III shows the same diffuse pattern as Echo IV, except for the presence of a series of multiples. The multiples found in Echo III are due to the subbottom profiler's acquisition power, becoming higher in very shallow areas, with depths not exceeding $200 \mathrm{~m}$.

The amplitude values obtained from the high-resolution seismic data did not show an obvious variation in relation to the above-described echoes I throughout IV, once the amplitude maps did not detect the small granulometric variations identified in cores related with these echoes. However, the portions with the highest amplitude values (areas in red and yellow, Fig. 6), correspond to Echo $V$ which is related to glacial deposits, probably morainal banks that would have slipped along slope when the glaciers reached the shelf break. These portions are in front of a fjord, presenting accumulation of glacial material. The Echo $\mathrm{V}$ area was not sampled due to the corer limitations of penetrating in thick sediments present therein. The irregular diffraction hyperbolae are the result of the upper slope uneven morphology with poorly-sorted sediment deposits.

Observing the physical parameters of the samples, it may be seen that, in a general way, the impedance values increase as sand grades are higher (Fig. 8), with a good correlation coefficient.
However, the impedance increment does not correlate well with the seismic amplitude values. If it is taken into consideration that the variation between the minimum and maximum impedance values was of the order of $23 \%$, and that sediments vary from silty sand to coarse silt, it may happen that this variation is not sufficiently significant to influence the amplitude values. In view of this, the echo-characters would be a better indication of small lithological variations than seismic amplitudes, while the last ones would be a good indication of deposits present in Echo $\mathrm{V}$. This also suggests that the sedimentation processes in the area, and not only the sediment type, influences the response of the seismic echo-character.

\section{CONCLUSION}

This work, based on high-resolution seismic profiles (3.5 kHz), amplitude maps and geologic samples, provides a comprehensive understanding concerning the bottom sedimentary distribution of the South Shetland Islands continental margin, combining the echo-characters to the regional bottom geology.

The echoes presented a good correlation with the geologic cores collected along the South Shetland's continental margin. A good correlation with the amplitude map was found only along the strip where deposits defined by Echo V occur. In that portion, samples were not collected due to difficulties of using gravity corer in sediments that possibly contain pebbles and boulders, and it was not possible to determine the impedance values related with that type of material, which, theoretically, may present values well above those observed in core samples.

The results show that in glaciomarine sediments, with similar physical properties, the echo-characters are a better indication of lithologic variations than the amplitude maps. 
In addition, deposits that are probably related with the Last Glacial Maximum were identified at the mouths of King George Island's fjords. Besides, the occurrence of sandier sediments inside the bays shows a stronger influence of glacial sediments than those portions of the outer continental shelf. This distribution is more evident at the Admiralty Bay, where the highest sand contents were found according to the interpretation of echo-characters, suggesting a differentiated glaciomarine dynamics when compared to the Maxwell Bay.

In order to understand all effective sedimentary processes in the Bransfield Strait and the South Shetland Islands, future investigations are required. They should comprise: geological sampling within each echo-character, with samples perpendicularly oriented considering the direction of glacier movements. As well as a detailed bathymetric survey should be done, in order to understand the topographic control exerted by the bottom in relation to sedimentation in the area, and to verify features that demonstrate the glaciers evolution and dynamics.

\section{ACKNOWLEDGEMENTS}

The authors gratefully acknowledge the CNPq for financing the project. We also are thankful to the PROANTAR and the Brazilian Navy for the support, making the project viable. We are also thankful to the NApOC Ary Rongel $(\mathrm{H}-44)$ crew, for their help along the OPERANTAR XXVIII, and to the two anonymous reviewers of this article for their valuable contributions, significantly improving the results of this study.

\section{REFERENCES}

ASSINE ML \& VESELY FF. 2008. Ambientes Glaciais. In: PEDREIRA DA SILVA AJ, ARAGÃO ANF \& MAGALHÃES AJC (Eds.). Ambientes de Sedimentação Siliciclástica do Brasil. São Paulo: Ed. Beca, p. 24-51.

AYRES NETO A. 2000. Uso da Sísmica de Reflexão de Alta Resolução e da Sonografia na Exploração Mineral Submarina. Brazilian Journal of Geophysics, 18(3): 241-255.

BARKER PF. 1982. The Cenozoic Subduction History of the Pacific Margin of the Antarctic Peninsula: Ridge Crest-trench Interactions. Journal of the Geological Society of London, 139: 787-801.

BARKER DHN \& AUSTIN JA. 1988. Rift Propagation, Detachment Faulting, and Associated Magmatism in Bransfield Strait, Antarctic Peninsula. Journal of Geophysical Research, 103: 24,017-24,043.

CONCEIÇÃo FV. 2009. Utilização do Backscatter de Sonares Multifeixe na Classificação Acústica do Fundo Oceânico: Um Exemplo de Aplicação na Enseada de Martel, Baía do Almirantado, Península Antártica. Final Graduation Paper on Geophysics, UFF, Rio de Janeiro, Brazil, 55 pp.
DAMUTH JE. 1975. Echo Character of the Western Equatorial Atlantic Floor and its Relationship to the Dispersal and Distribution of Terrigenous Sediments. Marine Geology, 18(1): 17-45.

DAMUTH JE \& HAYES DE. 1977. Echo character of the East Brazilian Continental Margin and its Relationship to Sedimentary Process. Marine Geology, 24(2): 73-96.

DUCK RW \& HEBERT RA. 2006. High-resolution shallow seismic identification of gas escape features in the sediments of Loch Tay, Scotland: tectonic and microbiological associations. Sedimentology, 53: 481-493.

FRANCIS JE, PIRRIE D \& CRAME JA (Eds.). 2006. Cretaceous-Tertiary High-Latitude Palaeoenvironments: James Ross Basin, Antarctica. London: Geological Society, Special Publications. 258, 216 pp.

GAMBOA LAP, BARROCAS SL \& MALDONADO PR. 1988. Investigações Geofísicas no Estreito de Bransfield e Mar de Bellingshausen - Antártica. In: Congresso Brasileiro de Geologia, 35., Proceedings... Belém: SBG, 5: 2343-2357.

GEORGE RA, GEE L, HILL ATW, THOMSON JA \& JEANJEAN P. 2002. High-Resolution AUV Surveys of the Eastern Sigsbee Escarpment. In: Proceedings of the Offshore Technology Conference, Houston, 2: 11851196.

HONG E \& CHEN IS. 2000. Echo Characters and Sedimentary Processes along a Rifting Continental Margin, Northeast of Taiwan. Continental Shelf Research, 20: 599-617.

KHIM BK \& YOON HI. 2003. Postglacial Marine Environmental Changes in Maxwell Bay, King George Island, West Antarctica. Polar Research, 22(2): 341-353.

LAINE EP, DAMUTH JE \& JACOBI R. 1986. Surficial Sedimentary Processes Revealed by Echo-character Mapping in the Western North Atlantic Ocean. In: VOGT PR \& TUCHOLKE BE (Eds.). The Geology of North America. Geological Soc. America, v. M: 427-450.

MOSHER DC \& SIMPKIN PG. 1999. Status and Trends of Marine HighResolution Seismic Reflection Profiling: Data Acquisition. Geoscience Canada, 26(4): 174-188.

REINECK HE \& SINGH LB. 1975. Depositional Sedimentary Environments. Berlin: Springer-Verlag. 551 pp.

ROSA KK, VIEIRA R, ACUÑA FJF \& SIMÕES JC. 2010. Geomorfologia Aplicada à Reconstrução e ao Monitoramento do Impacto das Mudanças Climáticas Ambientes Glaciais. Revista de Geografia, 27(1): 102-114.

SHARMA PV. 1997. Environmental and Engineering Geophysics. Cambridge University Press. 475 pp.

SIMMS AR, MILLIKEN KT, ANDERSON JB \& WELLNER JS. 2011. The Marine Record of Deglaciation of the South Shetland Islands, Antarctica since the Last Glacial Maximum. Quaternary Science Reviews, 30: 1583-1601. 
VERONEZ JÚNIOR P, BASTOS AC, PIZZIN BF, GAVA RD, QUARESMA VS \& SILVA CG. 2009. Sonar de Varredura Lateral e Sísmica de Alta Resolução Aplicados no Estudo de Ecofácies na Baía de Vitória - ES. Brazilian Journal of Geophysics, 27(3): 411-425.
YOON SH, YOON HI \& KANG CY. 2004. Late Quaternary Sedimentary Processes in Northern Continental Margin of the South Shetland Islands, Antarctica, The Sea. Journal of the Korean Society of Oceanography, 9 : $1-12$.

Recebido em 7 março, 2012 / Aceito em 23 maio, 2014

Received on March 7, 2012 / Accepted on May 23, 2014

\section{NOTES ABOUT THE AUTHORS}

Fabio José Guedes Magrani. M.Sc. in Marine Geology and Geophysics (Universidade Federal Fluminense), B.Sc. in Geophysics (Universidade Federal Fluminense). Researcher at the Laboratório de Processos Sedimentares e Ambientais (LAPSA-UFF). Working interest focused on geology and marine geophysics applied to sedimentary analysis, paleoenvironmental reconstruction and glaciomarine processes on polar environments.

Arthur Ayres Neto. Ph.D. in Marine Geophysics (University of Kiel, Germany). B.Sc. in Geology (Universidade Federal do Rio de Janeiro). The focal points of interest are geology and marine geophysics applied to engineering and environmental problems with emphasis on submarine slope stability and physical parameters of the sediments. 